\title{
Oral administration of insulin-like growth factor-I from colostral whey reduces blood glucose in streptozotocin-induced diabetic mice
}

\author{
Kyung-A Hwang ${ }^{1 *}$, Yu-Jin Hwang ${ }^{1}$, Woelkyu $\mathrm{Ha}^{2}$, Young-Kug $\mathrm{Choo}^{3}$ and Kisung $\mathrm{Ko}^{3}$ \\ ${ }^{1}$ Department of Agrofood Resources, National Academy of Agricultural Science, Rural Development Administration, \\ 160, Nokjiro, Gwonseon-gu, Suwon 441-853, Republic of Korea \\ ${ }^{2}$ Daesang RED Center, 125-8, Pyogyo-ri, Majang-myeon, Icheon-si, Gyeonggi-do 467-813, Republic of Korea \\ ${ }^{3}$ Department of Biological Science, College of Natural Sciences, Wonkwang University, Iksan 570-749, Republic of Korea
}

(Submitted 15 March 2011 - Final revision received 23 August 2011 - Accepted 23 August 2011 - First published online 10 October 2011)

\section{Abstract}

The aim of the present study was to investigate the effects of oral administration of the insulin-like growth factor-I-rich fraction (IGF-I-RF) from bovine colostral whey on the regulation of blood glucose levels in streptozotocin (STZ)-induced diabetic mice. We obtained a peptide fraction containing IGF-I ( $10 \mathrm{ng} / \mathrm{mg}$ protein) from Holstein colostrum within $24 \mathrm{~h}$ after parturition by using ultrafiltration. The blood glucose levels of STZ-induced diabetic mice fed with IGF-I-RF $(50 \mu \mathrm{g} / \mathrm{kg}$ per d) were significantly reduced by 11 and $33 \%$ at weeks 2 and 4, respectively $(P<0.05)$. The body weights of STZ-induced diabetic mice increased following the oral administration of the IGF-IRF. The kidney weights of STZ-induced diabetic mice decreased significantly $(P<0.05)$ following the administration of the IGF-I-RF, and the liver weights of STZ-induced diabetic mice decreased significantly $(P<0.05)$ following the administration of $50 \mu \mathrm{g} / \mathrm{kg}$ per $\mathrm{d}$ of the IGF-I-RF. The present results indicate that the IGF-I-RF obtained from Holstein colostrum could be a useful component for an alternative therapeutic modality for the treatment of diabetes in insulin-resistant patients.

\section{Key words: Insulin-like growth factor-I: Colostral whey: Blood glucose: Diabetes}

Diabetes mellitus is a common and serious disorder caused by a reduction in insulin secretion from the pancreatic $\beta$-cells or by insulin resistance in organs. The incidence of diabetes has been steadily increasing worldwide. According to the WHO, in 2000, an estimated 150 million people above the age of 20 years suffered from diabetes, and this number is expected to increase to 300 million by $2025^{(1,2)}$. Insulin deficiencies lead to increased glucose concentrations in the blood, which can damage many of the body's systems resulting in vascular complications related to coronary artery disease and cerebrovascular disease $\mathrm{e}^{(3-5)}$. The therapeutic measures for the treatment of hyperglycaemia include the use of insulin and other agents such as sulphonylureas and biguanides. These drugs may produce adverse side effects such as liver problems, lactic acidosis and diarrhoea ${ }^{(6,7)}$. For this reason, interest in evaluating natural products as potential treatments for diabetes has now increased in the scientific community ${ }^{(8,9)}$.

Bovine colostrum, the initial milk produced by cows in the first $48 \mathrm{~h}$ after parturition, contains growth factors such as insulin-like growth factors (IGF)-I and II, transforming growth factor- $\beta$ and epidermal growth factor, and pro-inflammatory cytokines such as IL-1 $\beta$, IL-6, TNF- $\alpha$ and interferon- $\gamma^{(10-15)}$ IGF-I is a predominant growth factor present in concentrations of approximately $500 \mathrm{mg} / \mathrm{l}$ in bovine colostrum and of $18 \mu \mathrm{g} / \mathrm{l}$ in human breast milk ${ }^{(16,17)}$. IGF-I shares sufficient structural and functional homologies with insulin, suggesting that it may exert similar biological effects. IGF-I appears to exert some insulin-like effects via high-affinity binding with its own receptor. Thus, IGF-I has been widely investigated in connection with the development of potential therapeutic modalities for the treatment of diabetes, owing to the similarity of its metabolic actions to those of insulin ${ }^{(18,19)}$. Recombinant human IGF-I (RH IGF-I) has been suggested as a component of a potential treatment for diabetic patients suffering from the insulin-resistance syndrome ${ }^{(20,21)}$; however, the safety of $\mathrm{RH}$ IGF-I remains a concern. Therefore, we attempted to isolate IGF-I from bovine colostrum as a natural source instead of using RH IGF-I. Additionally, since, to the best of our knowledge, the hypoglycaemic activity of the IGF-I-rich fraction (IGF-I-RF) from bovine colostral whey has not been previously reported in experimental diabetes, the aim of the present study was to investigate potential hypoglycaemic effects

Abbreviations: IGF, insulin-like growth factor; IGF-I-RF, insulin-like growth factor-I-rich fraction; RH IGF-I, recombinant human insulin-like growth factor-I; STZ, streptozotocin.

*Corresponding author: Dr K.-A. Hwang, fax +8231299 0504, email kah366@korea.kr 
using the IGF-I-RF from bovine colostral whey in streptozotocin (STZ)-induced diabetic mice.

\section{Materials and methods}

Insulin-like growth factor-I-rich fraction, recombinant human insulin-like growth factor-I and colostral whey

Similar to our previous study ${ }^{(22)}$, in the present study, Holstein colostrum was used for the isolation of the IGF-I-RF and collected within $24 \mathrm{~h}$ after parturition. The colostrum samples were centrifuged (at $5000 \mathrm{rpm}$ for $30 \mathrm{~min}$ at $4^{\circ} \mathrm{C}$ ) to remove milk fat. The separated skimmed milk was subsequently acidified to $\mathrm{pH} 4.5$ with $1 \mathrm{M}-\mathrm{HCl}$ and centrifuged (at $5000 \mathrm{rpm}$ for $30 \mathrm{~min}$ at $4^{\circ} \mathrm{C}$ ). According to the procedure described by Hossner \& Yemm $^{(23)}$, the separated whey was gradually passed through 30 and $1 \mathrm{kDa}$ ultrafiltration cartridges (Prep/ Scale-TFF; Millipore, Billerica, MA, USA) to separate the IGF-I-RF, the free form of IGF-I (Fig. 1). IGF-I in the ultrafiltered fractions was verified using SDS-PAGE ${ }^{(24)}$ and Western blotting ${ }^{(25)}$. IGF-I content was measured using sandwich ELISA $^{(26)}$. RH IGF-I was purchased from R\&D Systems (Minneapolis, MN, USA).

\section{Experimental animals and administration of the insulin-like growth factor-I-rich fraction}

Male imprinting control region mice ( 4 weeks old) were acquired from Orient (Seongnam, Korea), and five mice were randomly assigned to environmentally controlled, filtered cages (temperature $22^{\circ} \mathrm{C}$; relative humidity $55 \%$ ) and maintained under $12 \mathrm{~h}$ light $-12 \mathrm{~h}$ dark photocycle conditions. Mice were fed a standard diet (Purina Korea, Seongnam, Korea) during the 1-week adaptation period. Diabetes was induced in mice via an intraperitoneal administration of
$100 \mu \mathrm{l}$ STZ (Sigma Chemical Company, St Louis, MO, USA), which was dissolved in $0.01 \mathrm{M}$-citrate buffer $(\mathrm{pH} 4.5)$, at a dose of $45 \mathrm{mg} / \mathrm{kg}$ body weight (w/w). To prepare the control group, $100 \mu \mathrm{l}$ of $0 \cdot 01 \mathrm{M}$-citrate buffer $(\mathrm{pH} 4.5$ ) were injected in lieu of STZ. Blood glucose levels were then measured using blood glucose measuring kits (YD Diagnostics, Yongin, Korea) $24 \mathrm{~h}$ after STZ administration. Blood samples were obtained from mice after they were deprived of food for $16 \mathrm{~h}$. STZ-treated animals were considered diabetic when blood glucose levels exceeded $6.67 \mathrm{mmol} / \mathrm{l}$. After induction of diabetes, mice were randomly divided into five groups (n 5 per group). Both non-diabetic and diabetes-induced groups received PBS daily for 4 weeks. IGF-I-RF, RH IGF-I and colostral whey containing 50,5 and $0.5 \mu \mathrm{g}$ protein $/ \mathrm{kg}$ per $\mathrm{d}$, respectively, were given daily for 4 weeks to diabetes-induced mice via oral administration. IGF-I-RF, RH IGF-I and colostral whey were dissolved in PBS, and administered to diabetes-induced mice in $200 \mu$ l doses. Blood samples were obtained once per week in the morning for 4 weeks (on 7, 14, 21 and 28d). The animal experiments were conducted in accordance with the guidelines established by the Animal Care and Use Committee of the Rural Development Administration, and were approved by the committee.

\section{Measurement of body weights}

Body weights were measured daily and represented at $4 \mathrm{~d}$ intervals, beginning at the initiation of oral administration and continuing throughout the entire experimental period.

\section{Measurement of organ weights}

After 4 weeks, all mice were euthanised under deep anaesthesia with diethyl ether, and the heart, liver, spleen and kidney were weighed.

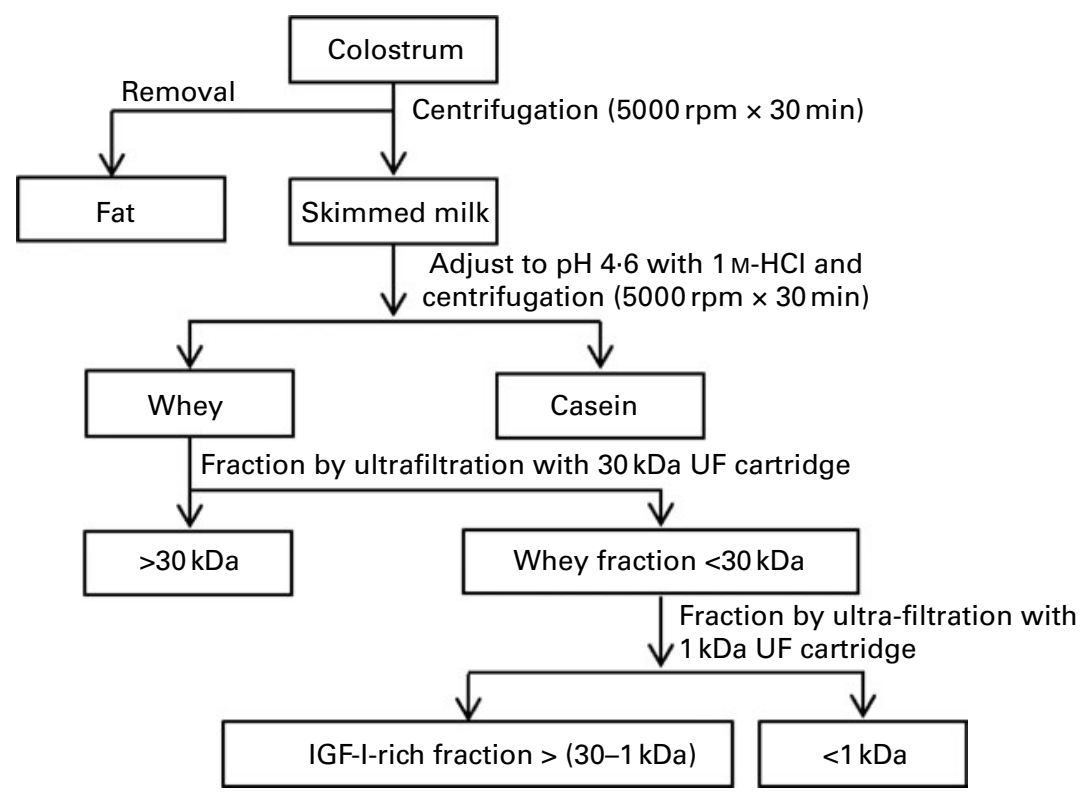

Fig. 1. Fractionation of the insulin-like growth factor (IGF)-I-rich fraction from Holstein colostrum using ultrafiltration (UF). 
Evaluation of the insulin-like growth factor-l-rich fraction by the oral glucose tolerance test

Mice were divided into five groups ( $n$ 5) and received the following treatment: group I, PBS; group II, STZ + PBS; group III, STZ + IGF-I-RF $(50 \mu \mathrm{g}$ protein $/ \mathrm{kg})$; group IV, $\mathrm{STZ}+\mathrm{RH}$ IGF-I $(50 \mu \mathrm{g}$ protein $/ \mathrm{kg})$; group V, STZ + colostral whey $(50 \mu \mathrm{g}$ protein $/ \mathrm{kg})$. Glucose $(2 \cdot 0 \mathrm{~g} / \mathrm{kg})$ was administered orally via needles. Blood was drawn from a tail vein at 0,15 , 30, 45, 60, 90 and $120 \mathrm{~min}$.

\section{Determination of blood glucose, insulin and tissue TAG levels}

Blood glucose levels were measured using blood glucose measuring kits (YD Diagnostics). Blood insulin levels were measured by the insulin ELISA kit (Millipore). Tissue TAG was extracted using the Bligh \& Dyer method ${ }^{(27)}$ and measured using a Triglyceride Reagent (Diagnostic Chemicals Limited, Stamford, CT, USA).

\section{Statistical analysis}

Statistical analysis was performed with SPSS statistical software version 12.0. Descriptive statistics are expressed as means and standard deviations. One-way ANOVA was performed and when the values were significant $(P<0.05)$, the differences of the mean values were determined using Duncan's multiple range tests.

\section{Results}

\section{Identification of the insulin-like growth factor-I-rich} fraction and insulin-like growth factor-I

The molecular weight of the recovered free IGF-I $(7 \cdot 6 \mathrm{kDa})$ was identified in the fraction obtained between 1 and $30 \mathrm{kDa}$ ultrafiltration membranes by using SDS-PAGE and Western blotting (Fig. 2). IGF-I concentration in the IGF-I-RF obtained was $10 \mathrm{ng} / \mathrm{mg}$ protein.

(A)

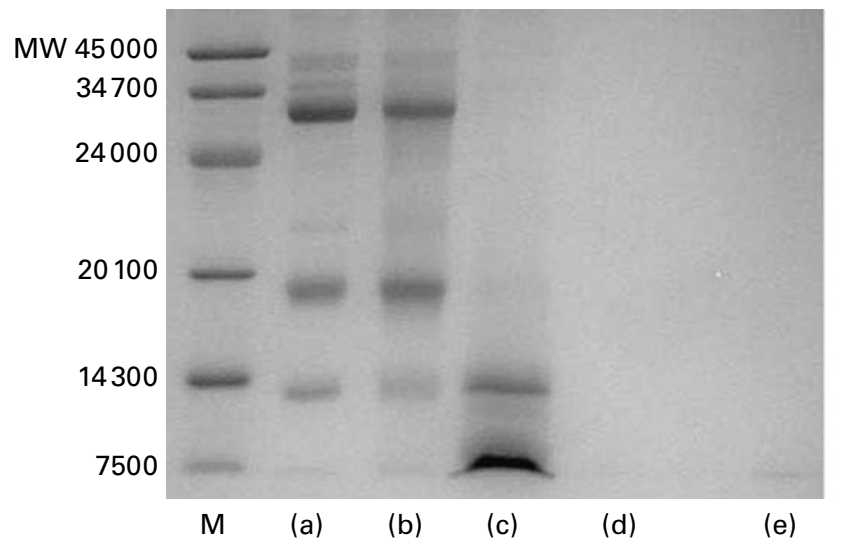

\section{Effects on blood glucose levels}

Diabetes-induced mice were orally administered IGF-I-RF, RH IGF-I and colostral whey for 4 weeks. Blood glucose levels in the non-diabetic and STZ-induced diabetic groups fed with IGF-I-RF, RH IGF-I and colostral whey from 1 to 4 weeks are shown in Fig. 3. The IGF-I-RF and RH IGF-I groups had significantly reduced $(P<0.05)$ blood glucose levels compared with the levels of the colostral whey group. The blood glucose levels returned to normal in a dose-dependent manner in the IGF-I-RF group, and these results were similar to the decreased blood glucose levels of the RH IGF-I group, which was used as the positive control.

\section{Effects on body weights}

The body weights of the STZ-induced diabetic control group decreased steadily during the entire experimental period (Fig. 4). However, the body weights of the IGF-I-RF, RH IGF-I and colostral whey groups increased slightly. Overall, the body-weight gain increased more effectively in the $\mathrm{RH}$ IGF-I or IGF-I-RF group than in the group fed with bovine colostral whey.

\section{Effects on organ weights}

The organ weights of the individual groups are shown in Table 1. Heart weights of all experimental groups were similar to those of the normal group. Kidney, spleen and liver weights of the STZ-induced diabetic group were significantly $(P<0.05)$ increased compared with those of the normal group. Kidney and spleen weights for the IGF-I-RF, RH IGF-I and colostral whey groups were significantly $(P<0.05)$ reduced. The liver weights of the IGF-I-RF and RH-IGF-I groups were reduced and were similar to those of the control group, and this dose-dependent reduction was significant $(P<0 \cdot 05)$. No significant differences in the colostral whey group were observed.

(B)

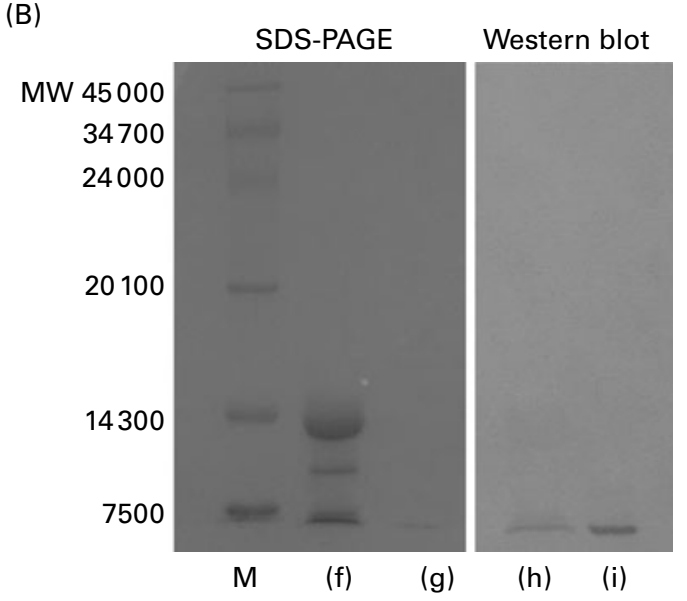

Fig. 2. (A) SDS-PAGE patterns of isolated fractions from colostral whey and (B) SDS-PAGE and Western blot patterns of the insulin-like growth factor (IGF)-I-rich fraction. MW, molecular weight; M, marker. (a) Whey, (b) $>30 \mathrm{kDa}$ fraction, (c) 1-30 kDa fraction, (d) $<1 \mathrm{kDa}$ fraction, (e) standard IGF-l, (f) 1-30 kDa fraction, (g) standard IGF-I, (h) $1-30 \mathrm{kDa}$ fraction and (i) standard IGF-I. 


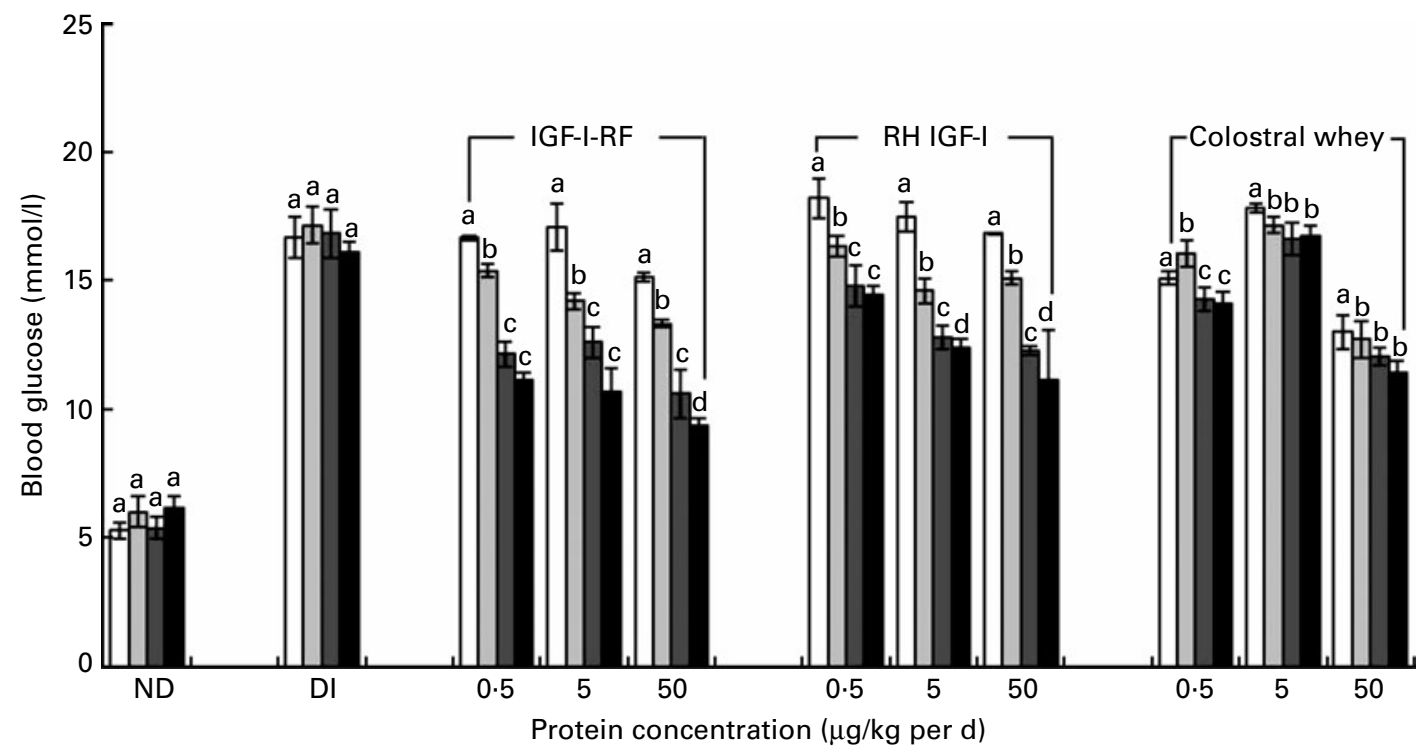

Fig. 3. Effects of insulin-like growth factor-I-rich fraction (IGF-I-RF), recombinant human IGF-I (RH IGF-I) and colostral whey on blood glucose levels in streptozotocin-induced diabetic mice. ND, non-diabetic mice; $\mathrm{DI}$, diabetes-induced mice. ${ }^{\mathrm{a}, \mathrm{b}, \mathrm{c}, \mathrm{d}}$ Mean values with unlike letters for the same sample and level of protein concentration were significantly different $(P<0.05)$. $\square, 1$ week; $\square, 2$ weeks; $\square, 3$ weeks; $\mathbf{\square}, 4$ weeks.

Effects of the insulin-like growth factor-I-rich fraction on the oral glucose tolerance test

In the oral glucose tolerance test, the highest rise in blood glucose occurred in STZ-induced control mice at $30 \mathrm{~min}$ after oral glucose ingestion and decreased slowly after $30 \mathrm{~min}$ (see Supplementary data 1 of the supplementary material, available online at http://www.journals.cambridge. org/bjn). The IGF-I-RF and RH IGF-I significantly suppressed the increase in blood glucose in comparison with STZ $(P<0 \cdot 05)$. The IGF-I-RF and RH IGF-I led to a decrease in blood glucose levels by 16.70 (SD 1.49) and 15.81 (SD 3.07 ) $\mathrm{mmol} / \mathrm{l}$ at $60 \mathrm{~min}$, and by 13.93 (SD 1.06 ) and 13.17 (SD 1.58$) \mathrm{mmol} / 1$ at $120 \mathrm{~min}$, respectively.

\section{Effects of the insulin-like growth factor-I-rich fraction on blood insulin and tissue TAG levels}

The effects of the IGF-I-RF on blood insulin and tissue TAG levels in the STZ-induced diabetic group are shown in Supplementary data 2 of the supplementary material (available online at http://www.journals.cambridge.org/bjn). Blood insulin levels significantly increased in the IGF-I-RF, RH IGF-I and colostral whey groups compared with those in the STZ-induced diabetic group $(P<0 \cdot 05)$. Intracellular concentrations of TAG decreased in the liver of IGF-I-RFand RH IGF-I-treated mice compared with those in STZinduced diabetic mice; however, the difference was not significant.

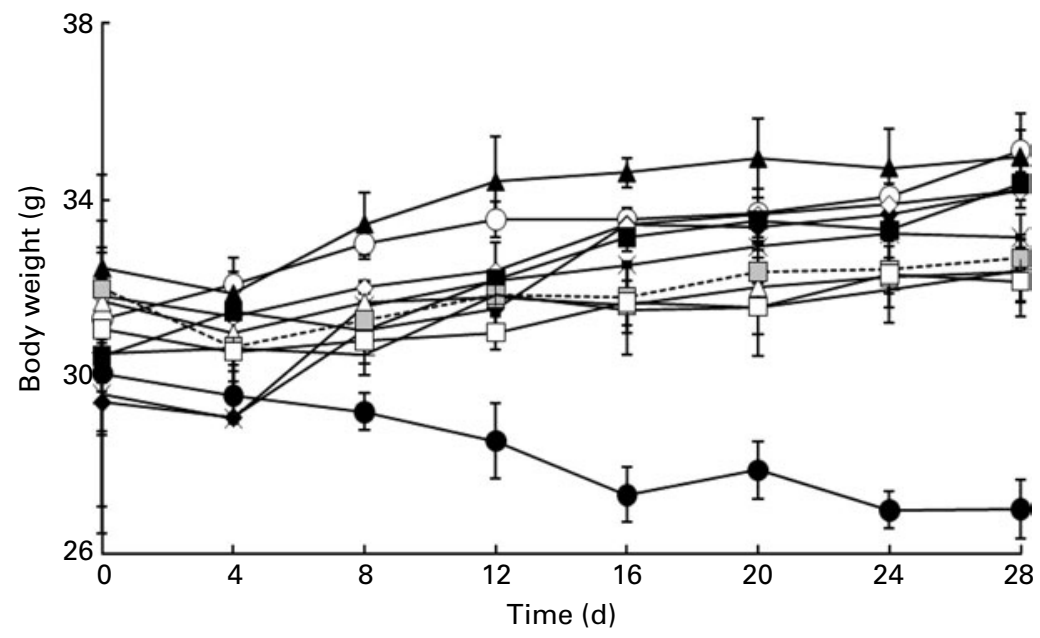

Fig. 4. Effect on the body weight of streptozotocin-induced diabetic mice fed with insulin-like growth factor-I-rich fraction (IGF-I-RF), recombinant human IGF-I

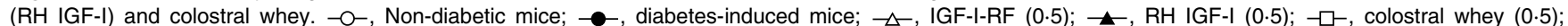
$\rightarrow-$, IGF-I-RF (5); $\rightarrow$, RH IGF-I (5); - +-, colostral whey (5); $\diamond-$, IGF-I-RF (50); $\bullet-$, RH IGF-I (50); .- $\square \cdot-$, colostral whey (50). 
Table 1. Effects of insulin-like growth factor-I-rich fraction (IGF-I-RF), recombinant human IGF-I (RH IGF-I) and colostral whey on the organ weights of streptozotocin-induced diabetic mice

(Mean values and standard deviations)

\begin{tabular}{|c|c|c|c|c|c|c|c|c|c|c|}
\hline \multirow[b]{3}{*}{ Group } & \multirow{3}{*}{$\begin{array}{c}\text { Dose } \\
(\mu \mathrm{g} / \mathrm{kg} \text { per } \mathrm{d})\end{array}$} & \multirow[b]{3}{*}{ Body weight $(\mathrm{g})$} & \multicolumn{8}{|c|}{ Relative organ weight ( $\mathrm{g} / 100 \mathrm{~g}$ body weight) ${ }^{*}$} \\
\hline & & & \multicolumn{2}{|c|}{ Heart } & \multicolumn{2}{|c|}{ Kidney } & \multicolumn{2}{|c|}{ Liver } & \multicolumn{2}{|c|}{ Spleen } \\
\hline & & & Mean & SD & Mean & SD & Mean & SD & Mean & SD \\
\hline Non-diabetic mice & - & $35 \cdot 11^{a}$ & 0.42 & 0.05 & $1.529^{a}$ & 0.1 & $3.982^{\mathrm{a}}$ & 1.04 & $0.347^{\mathrm{a}}$ & 0.06 \\
\hline Diabetes-induced mice & - & $27 \cdot 01^{\mathrm{c}}$ & 0.56 & 0.15 & $2 \cdot 284^{\mathrm{b}}$ & 0.32 & $6 \cdot 061^{\mathrm{c}}$ & 0.71 & $0.703^{b}$ & 0.19 \\
\hline \multirow[t]{3}{*}{ IGF-I-RF† } & 0.5 & $34.97^{a}$ & 0.43 & 0.05 & $1.707^{\mathrm{a}}$ & 0.15 & $4.578^{a, b}$ & 0.89 & $0.352^{\mathrm{a}}$ & 0.45 \\
\hline & 5 & $33 \cdot 16^{\mathrm{b}}$ & 0.46 & 0.2 & $1.707^{\mathrm{a}}$ & 0.73 & $4.789^{a, b}$ & 0.26 & $0.365^{a}$ & 0.09 \\
\hline & 50 & $34 \cdot 22^{\mathrm{a}}$ & 0.43 & 0.05 & $1 \cdot 616^{\mathrm{a}}$ & 0.46 & $4.509^{a, b}$ & 0.46 & $0.348^{\mathrm{a}}$ & 0.11 \\
\hline \multirow[t]{3}{*}{ RH IGF-I† } & 0.5 & $32 \cdot 36^{\mathrm{b}}$ & 0.47 & 0.06 & $1.740^{\mathrm{a}}$ & 0.09 & $4 \cdot 713^{\mathrm{a}, \mathrm{b}}$ & 1.02 & $0.386^{\mathrm{a}}$ & 0.07 \\
\hline & 5 & $34 \cdot 36^{\mathrm{a}}$ & 0.43 & 0.07 & $1.548^{\mathrm{a}}$ & 0.45 & $4.395^{a, b}$ & 0.66 & $0.343^{a}$ & 0.07 \\
\hline & 50 & $34 \cdot 21^{a}$ & 0.44 & 0.08 & $1.520^{\mathrm{a}}$ & 0.11 & $4 \cdot 209^{\mathrm{a}}$ & 1.47 & $0.362^{a}$ & 0.11 \\
\hline \multirow[t]{3}{*}{ Colostral whey† } & 0.5 & $32 \cdot 16^{\mathrm{b}}$ & 0.45 & 0.03 & $1.903^{\mathrm{a}}$ & 0.16 & $5 \cdot 311^{\mathrm{c}}$ & 1.02 & $0.339^{a}$ & 0.04 \\
\hline & 5 & $32 \cdot 41^{\mathrm{b}}$ & 0.46 & 0.04 & $1.898^{\mathrm{a}}$ & 0.42 & $5.239^{b, c}$ & 1.44 & $0.364^{\mathrm{a}}$ & 0.06 \\
\hline & 50 & $32 \cdot 68^{\mathrm{b}}$ & 0.46 & 0.07 & $1.845^{\mathrm{a}}$ & 0.28 & $5 \cdot 233^{b, c}$ & 0.69 & $0.367^{\mathrm{a}}$ & 0.08 \\
\hline
\end{tabular}

${ }^{\mathrm{a}, \mathrm{b}, \mathrm{c}}$ Mean values within a column with unlike superscript letters were significantly different $(P<0.05)$.

* The organ weights were expressed as the ratio of body weight:organ weight.

† After diabetes was induced, mice were orally administered IGF-I-RF, RH IGF-I and colostral whey for 4 weeks.

\section{Discussion}

Current research worldwide is aimed at developing bioactive food and new drug materials from natural resources. Along similar lines, our research is directed towards exploring food materials that have the potential to regulate metabolic syndromes such as diabetes by using natural ingredients or waste materials. In the present study, we hypothesised that the IGF-I-RF from colostral whey could imitate insulin function. To evaluate this, the IGF-I-RF was isolated and purified from the colostrum, and its antidiabetic activity was analysed by measuring blood glucose levels, body weight, organ weight and blood insulin levels.

The results of several studies ${ }^{(21,28-30)}$ suggested that $\mathrm{RH}$ IGF-I is involved in the regulation of metabolic control in patients with type 2 diabetes mellitus via a reduction in insulin resistance by decreasing blood glucose, serum TAG and total cholesterol levels. Moreover, $24 \mathrm{~h}$ creatinine clearance increases when RH IGF-I is injected into diabetic patients. Therefore, we isolated IGF-I from the colostrum as a natural source, instead of using RH IGF-I, and confirmed its effects on blood glucose reduction through oral administration of the isolated IGF-I-RF in mice.

A number of previous studies have focused on the effects of RH IGF-I in type 2 diabetic patients ${ }^{(21,31-33)}$. RH IGF-I $(120 \mu \mathrm{g} / \mathrm{kg})$ was subcutaneously injected into type 2 diabetic patients twice per $\mathrm{d}$ for $5 \mathrm{~d}$, and this resulted in a $2 \cdot 5$-fold elevation of free IGF-I above basal levels. The fasting blood glucose level decreased by $30 \%$, whereas insulin and C-peptide levels decreased by $50 \%$, suggesting that RH IGF-I attenuated insulin resistance ${ }^{(31)}$. Schalch et al. ${ }^{(21)}$ used doses of RH IGF-I as high as $160 \mu \mathrm{g} / \mathrm{kg}$ in twelve patients and reported improvements in fasting glucose, insulin and C-peptide levels. The mechanism by which IGF-I improves glycaemic control and insulin sensitivity remains to be elucidated. The observed reductions in fasting blood glucose levels suggest that RH IGF-I exerts a significant effect on the production of hepatic glucose, which is the principal determinant of fasting glucose levels ${ }^{(34)}$. In addition, IGF-I also enhances glucose output, increasing fatty acid oxidation and glucose uptake in skeletal muscles ${ }^{(35,36)}$. The present results also showed that the orally administered IGF-I-RF improved blood glucose levels in STZ-induced diabetic mice; a trend very similar to that observed with pure IGF-I (RH IGF-I) was evident. Orally administered bovine colostral whey also reduced blood glucose levels in STZ-induced diabetic mice. Therefore, bovine colostral IGF-I may be used to enhance insulin sensitivity in healthy subjects and may prove particularly effective in the treatment of insulin-resistant diabetics.

The lack of insulin synthesis due to the damage of pancreatic $\beta$-cells by STZ injection induces weight loss via an imbalance in glucose metabolism ${ }^{(37,38)}$. In the present study, we showed that all STZ-induced diabetic mice lost weight in the first $4 \mathrm{~d}$ following STZ, but all treatments (IGF-I-RF, RH IGF-I and colostral whey) resulted in weight gain beginning $5 \mathrm{~d}$ after the initial oral administration. We summarise that the weight loss observed in STZ-induced diabetic mice beginning $4 \mathrm{~d}$ after oral ingestion of the aforementioned substances may have been attributable to the lack of insulin secretion and fat degradation induced by the destruction of pancreatic $\beta$-cells, as has been concluded in the previous studies of Smith et $a l .{ }^{(39)}$ and Kadowaki et al. ${ }^{(40)}$. With regard to the present results, the recovery of body weights in STZ-induced diabetic mice may have also been attributable to absorption of the orally administered IGF-I-RF from bovine colostral whey. Therefore, oral supplementation with colostral whey and the IGF-I-RF may prove useful in preventing body-weight reduction in subjects suffering from diabetes mellitus.

Diabetes-associated liver hypertrophy was attributable to a lack of insulin synthesis, resulting in a failure to metabolise ingested glucose and subsequent storage of lipids within the liver ${ }^{(37)}$. In the present study, an increase in liver weights was also observed in STZ-induced diabetic control mice. However, the liver weights of non-diabetic mice were statistically 
identical to those of mice fed RH IGF-I and were lower in mice fed the IGF-I-RF than in STZ-induced diabetic control mice. The liver weights of STZ-induced diabetic mice fed with $50 \mu \mathrm{g} / \mathrm{kg}$ per $\mathrm{d}$ of the IGF-I-RF did not significantly differ from those of normal mice. Thus, the present results indicate that the administration of the IGF-I-RF obtained from colostral whey exerted an ameliorative effect on liver hypertrophy associated with diabetes mellitus.

In addition, the kidney weights of the STZ-induced diabetic group were significantly $(P<0.05)$ higher than those of the normal group, and kidney weights significantly $(P<0.05)$ decreased in the IGF-I-RF, RH IGF-I and colostral whey groups.

Sochor et al. ${ }^{(41)}$ reported that orally administered RH IGF-I significantly reduced the kidney weights in STZ-induced diabetic mice and observed a positive relationship between kidney hypertrophy and hyperglycaemia in diabetic mice. STZ-induced diabetic rats also have been shown to have larger kidneys than non-diabetic rats ${ }^{(42)}$. The rate of kidney hypertrophy over the first $7 \mathrm{~d}$ of induced diabetes in mice was correlated with blood glucose concentrations. Over a wide range of blood glucose concentrations (6.44-18.89 mmol/1), kidney weights, protein contents and protein:DNA ratios were closely correlated with blood glucose levels ${ }^{(42)}$. Alternatively, it has been reported that a high concentration of glucose metabolised into UDP-galactose or glycogen is a cause of cell membrane hypertrophy. Subsequently, glycogen stored in mesangial cells of the glomerulus results in kidney hypertrophy ${ }^{(43)}$

The findings of the present study are particularly interesting because oral administration of a peptide-enriched fraction with a molecular weight corresponding to that of IGF-I significantly reduced blood glucose levels in a STZ-induced diabetic mouse model. These peptide fractions also improved the weights of kidney and liver in STZ-induced diabetic mice. The trend towards a decrease in blood glucose levels in STZ-induced diabetic mice after feeding was similar to that observed with the administration of insulin. Therefore, the present study confirmed that the oral consumption of fractions including IGF helps in controlling blood glucose levels in patients with diabetes mellitus. However, future studies and clinical trials are required to investigate the metabolic mechanism related to blood glucose reduction.

\section{Acknowledgements}

This study was supported by a grant (code no. PJ0074922011) from the Rural Development Administration, Republic of Korea. All authors designed the study. K.-A. H. and Y.-J. H. conducted the experiments and drafted the manuscript. W. H., Y.-K. C. and K. K. provided helpful technical advice and supervised the entire work. The authors declare that they have no conflicts of interest.

\section{References}

1. King H, Aubert RE \& Herman WH (1998) Global burden of diabetes. 1995-2025: prevalance, numericial estimates, and projections. Diabetes Care 21, 1414-1431.
2. World Health Organization (2010) Country and regional data on diabetes. http://www.who.int/diabetes/facts/world_figures/ en/ (accessed 2010).

3. Gary GA, Shahwar I, Sheng W, et al. (2011) The hypoglycaemic effect of pumpkins as anti-diabetic and functional medicines. Food Res Int 44, 862-867.

4. Oh WK, Lee CH, Lee MS, et al. (2005) Antidiabetic effects of extracts from Psidium guajava. J Ethnopharmacol 96, 411-415.

5. Ciresi A, Amato MC, Criscimanna A, et al. (2007) Metabolic parameters and adipokine profile during GH replacement therapy in children with GH deficiency. Eur J Endocrinol 156, 353-360.

6. Bhatnagar D (1998) Lipid-lowering drugs in the management of hyperlipidaemia. Pharmacol Ther 79, 205-230.

7. May LD, Lefkowitch JH, Kram MT, et al. (2002) Mixed hepatocellular-cholestatic liver injury after pioglitazone therapy. Ann Intern Med 136, 449-452.

8. Roh SG, Kim KH \& Choi WC (2009) Antidiabetic effects of leaves extracts of Psidium guajava $L$. and Lagerstroemia speciosa L. in STZ-induced rats. J Life Sci 19, 40-45.

9. Rakesh KS, Shikha M, Dolly J, et al. (2009) Antidiabetic effect of Ficus bengalensis aerial roots in experimental animals. $J$ Ethnopharmacol 123, 110-114.

10. Playford RJ, Macdonald CE \& Johnson W (2000) Colostrum and milk-derived peptide growth factors for the treatment of gastrointestinal disorders. Am J Clin Nutr 72, 5-14.

11. Pakkanen R \& Aalto J (1997) Growth factors and antimicrobial factors of bovine colostrum. Int Dairy 7, 285-297.

12. Floren $\mathrm{CH}$, Chinenye S \& Elfstrand L (2006) ColoPlus, a new product based on bovine colostrum, alleviates HIV-associated diarrhoea. Scand J Gastroenterol 41, 682-686.

13. Tripathi V \& Vashishtha B (2006) Bioactive compounds of bovine colostrum. Food Rev Int 22, 225-244.

14. Kelly GS (2003) Bovine colostrums: a review of clinical uses. Altern Med Rev 8, 378-394.

15. Davison G \& Diment BC (2010) Bovine colostrum supplementation attenuates the decrease of salivary lysozyme and enhances the recovery of neutrophil function after prolonged exercise. BrJ Nutr 103, 1425-1432.

16. Baxter RC, Zaltsman Z \& Turtle JR (1984) Immunoreactive somatomedin-C/IGF-I and its binding protein in human milk. J Clin Endocrinol Metab 58, 955-959.

17. Vacher PY \& Blum JW (1993) Age dependency of IGF-I, insulin protein and immunoglobulin concentrations and gamma glutamyl transferase activity in first colostrum of dairy cows. Milchwissenschaft 48, 423-425.

18. Rinderknecht E \& Humbel RE (1978) The amino acid sequence of human IGF-I and its structural homology with proinsulin. J Biol Chem 253, 2769-2776.

19. Daughaday WH \& Rotwein P (1989) IGF-I and II. Peptide, messenger ribonucleic acid and gene structures, serum, and tissue concentration. Endocr Rev 10, 68-91.

20. Kolaczynski JW \& Caro JF (1994) IGF-I therapy in diabetes: physiological basis, clinical benefits and risks. Ann Int Med 120, 47-55.

21. Schalch DS, Turman NY, Marcsisin VS, et al. (1993) Shortterm effects of RH IGF-I on metabolic control of patients with type II diabetes. J Clin Endocrinol Metab 77, 1563-1568.

22. Hwang KA, Ha WK, Yang HJ, et al. (2006) Effect of IGF-I rich fraction from bovine colostral whey on murine immunity. Asian-Aust J Anim Sci 19, 297-304.

23. Hossner KL \& Yemm RS (2000) Improved recovery of insulin-like growth factors (IGFs) from bovine colostrum using alkaline diafiltration. Biotechnol Appl Biochem 32, 161-166. 
24. Laemmli UK (1970) Cleavage of structural proteins during the assembly of the head of bacteriophage T4. Nature $\mathbf{2 2 7}$, 680-685.

25. Holsapple MP, McNerney PJ, Tucker AN, et al. (1984) Effects of $N$-nitro-sodimetylamine on humoral immunity. J Pharmacol Exp Ther 229, 493-500.

26. Battelli MG, Abbondanza A, Musiani S, et al. (1999) Determination of xanthine oxidase in human serum by a competitive enzyme-linked immunosorbent assay. Clin Chim Acta 281, 147-158.

27. Bligh EG \& Dyer WJ (1959) A rapid method for total lipid extraction and purification. Can J Biochem Physiol 37, 911-917.

28. Clemmons DR, Moses AC, Sommer A, et al. (2005) Rh/IGF-I/ rhIGFBP-3 administration to patients with type 2 diabetes mellitus reduces insulin requirements while also lowering fasting glucose. Growth Horm IGF Res 15, 265-274.

29. Carroll PV, Umpleby M, Ward GS, et al. (1997) RhIGF-I administration reduces insulin requirements, decreases growth hormone secretion, and improves the lipid profile in adults with IDDM. Diabetes 46, 1453-1458.

30. Hirschberg R, Kopple J, Lipsett P, et al. (1999) Multicenter clinical trial of recombinant human insulin-like growth factor I in patients with acute renal failure. Kidney Int $\mathbf{5 5}$, 2423-2432.

31. Zenobi PD, Jaeggi-Groisman SE, Riesen WF, et al. (1992) IGF-I improves glucose and lipid metabolism in type 2 diabetes mellitus. J Clin Invest 90, 2234-2241.

32. Jabris N, Schalch DS, Schwartz SL, et al. (1994) Adverse effects of RH IGF-I in obese insulin-resistant type II diabetic patients. Diabetes 43, 369-374.

33. Moses AC, Young SC, Morrow LA, et al. (1996) RH IGF-I increases insulin sensitivity and improves glycemic control in type II diabetes. Diabetes 45, 91-100.
34. Gabbay RA \& Moses AC (1999) IGF in the treatment of diabetes. In The IGF System: Molecular Biology, Physiology, and Clinical Applications, pp. 721-737 [R Rosenfeld and C Roberts Jr, editors]. Totowa, NJ: Humana Press.

35. Kim JH, Jung WS, Choi NJ, et al. (2009) Health-promoting effects of bovine colostrum in type 2 diabetic patients can reduce blood glucose, cholesterol, triglyceride and ketones. J Nutr Biochem 20, 298-303.

36. Ciaraldi TP, Carter L, Rehman N, et al. (2002) Insulin and insulin-like growth factor-1 action on human skeletal muscle: preferential effects of insulin-like growth factor-1 in type 2 diabetic subjects. Metabolism 51, 1171-1179.

37. Grey NJ, Karl I \& Kipnis DM (1975) Physiologic mechanism in the development of starvation ketosis in man. Diabetes 24, 10-16

38. Foster DW \& McGarry JD (1983) The metabolic derangements and treatment of diabetic ketoacidosis. $N$ EngI J Med 309, 159-169.

39. Smith OL, Wong CY \& Gelfand RA (1989) Skeletal muscle proteolysis in rats with acute streptozotocin-induced diabetes. Diabetes 38, 1117-1122.

40. Kadowaki M, Harada N, Takahashi S, et al. (1989) Differential regulation of degradation of myofibrillar and total protein in dietary protein and starvation. J Nutr 119, 471-477.

41. Sochor M, Kunjara S, Baquer NZ, et al. (1991) Regulation of glucose metabolism in livers and kidneys of NOD mice. Diabetes 40, 1467-1471.

42. Seyer-Hansen K (1977) Renal hypertrophy in experimental diabetes relation to severity of diabetes. Diabetologia $\mathbf{1 3}$ $141-143$

43. Steer KA, Sochor M \& McLean P (1985) Renal hypertrophy in experimental diabetes: changes in pentose phosphate pathway activity. Diabetes 34, 485-490. 